Lamanauskas, V., Augienè, D., \& Makarskaitė-Petkevičienè, R. (2020). Primary school teachers' educational research: Educational practice and professional development context, International Journal of Cognitive Research in Science, Engineering and Education (IJCRSEE), 8(3), 1-18.

Original scientific paper

UDK:

Received: September, 09.2020.

Revised: September, 30.2020.

37.091.12:005.963(474.5)"2019"

Accepted: October, 12.2020.

doi: $10.23947 / 2334-8496-2020-8-3-1-18$

\title{
Primary School Teachers' Educational Research: Educational Practice and Professional Development Context
}

\author{
Vincentas Lamanauskas ${ }^{1 *}$, Dalia Augiené ${ }^{1}$, Rita Makarskaitè-Petkevičiené2
}

1Šiauliai University, Institute of Education, Lithuania, e-mail: vincentas.lamanauskas@su.lt; augiene@gmail.com

${ }^{2}$ Institute of Educational Sciences, Vilnius University, Lithuania, e-mail: rita.makarskaite-petkeviciene@fsf.vu.It

\begin{abstract}
Teacher research activity is an important complex part of their work. Therefore, alongside with the other, their important professional competences, teacher research activity competence becomes a significant one. Teacher's activity space has widened a lot. Carrying out various research, the teacher uses the obtained information firstly for their activity improvement. It is obvious that there is a lack of reliable research on this question. A deep gap exists between educational research and educational practice. This research aimed to ascertain primary school teachers' position on educational research question. The research was carried out in 2019, in which 106 primary school teachers from various Lithuanian schools took part. A two-part research instrument was applied, which consisted of open-ended and closed-ended questions. A descriptive qualitative and quantitative content analysis was carried out. Though most of the teachers thought that educational research was important for their practical activity, however, the biggest gap between educational research and educational practice is most frequently determined by the lack of teacher competence in this sphere. There exists an obvious teacher support need as well as teacher professional development needs in the aspect of research availability/accessibility and its use in educational practice.
\end{abstract}

Keywords: content analysis, educational research, qualitative research, primary school teachers.

\section{Introduction}

Teachers' carried out research activity is one of the complex parts of their professional activity. In this case, one speaks about the teacher as researcher. The research activity of such a teacher is manifold. Firstly, it enables teachers to research and to better cognise teaching/learning situation, to think of educational actions, to convince themselves in the applied teaching method effectiveness and so on. Secondly, research activity is important getting to know one's learners, recognising their abilities, establishing relations with them and seeking the educational process to be successful and pleasant for both educational process participant sides. Thirdly, understanding of educational research activity is useful for the management of students' research-based projects. Thus, today's teachers have to be able to analyse data about education process, carry out the pedagogical activity and school community research, apply research results improving education quality, developing their own professional activity, initiating educational changes and so on.

Teacher as researcher concept is based on continual professional development. Therefore, it is necessary to enhance general education teachers' abilities in making students interested in research activity, to guide students' scientific research activity. In general, it is necessary to accentuate that the gap still prevails between educational research and practice (Broekkamp and van Hout-Wolters, 2007; Weinberger, 2018). Teacher research activity at school and education quality improvement are directly related. On the other hand, teacher as researcher competence is formed not only during the studies at university or performing pedagogical practice, but also during continual professional improvement activities, as for example, reflexive research (Lamanauskas and Augienè, 2016).

Janiūnaitè (2004) draws attention to the fact that teachers' self-reflection and carried out pedagogical activity research studies are useful not only for the teachers themselves, but also for the school academic community. They provide exhaustive information, which could be used in the improvement of teaching and learning ways or strategies. The overall aim of the educational research in schools is, first of all, to develop the skills of school managers and teachers to analyse and purposefully use the data available at school for the activity quality improvement, orienting to the improvement of the school activity. It is obvious that it is difficult to manage various available scientific and applied, institutional, national and international

"Corresponding author: vincentas.lamanauskas@su.lt 
research data, to understand their meaning for educational process modernisation. Without doubt, teachers' competence in the educational research sphere is important because it is one of the instruments of their professional development (Gu and Wang, 2006; Marcos and Tillema, 2006), teacher research is an effective teachers' learning and improvement model (Nezvalova, 2011). The research carried out in Turkey showed that even $32 \%$ of teachers had never been seriously interested or contemplated on the research results since the beginning of their work as teachers (Beycioglu, et al., 2010). The research carried out earlier in Turkey, in which 265 primary school teachers took part, showed that teachers would like to be researchers, they understood this as one of the ways of professional improvement. In other research studies, closer collaboration is accentuated between scientists and teachers (Ekiz, 2006), teachers expect that research should contribute to educational practice, and researchers should have practice experience (Cekic, et al., 2018). On the other hand, there also exists a negative attitude towards educational research, its usefulness and/or influence on educational practice (Drill, et al., 2013), there is a lot of discussion regarding educational research result practical significance (Bitinas, 1998). Finally, educational research result dissemination remains very problematic in other aspects, e.g., accessibility, usability and other (Shreeve, 2004).

In Lithuania, this question is of interest, though not much research is done. Vilkonis and Vilkonienè (2009) analysed educational research studies, carried out not by professional researchers, scientists, but by teachers and administrators and, with the support of 16 expert group, revealed problems of the research carried out by pedagogues in comprehensive schools (students' achievements, educational environment research), prevailing research methods and factors, having an influence on research quality (attitudes, professional competences, resources, teacher support and so on). The attitude of students' (pre-service teachers') after completing their practice towards research activity in comprehensive school was analysed in the research carried out by Pečiuliauskienè (2008). Having compared future teachers' attitudes about research activity and managing research activity competence, it was established that students more favourably evaluated research activity competence than managing students' research activity competence. The researcher indicates that it is difficult to define teacher research activity competence, research activity is diverse and includes various activities (participation in scientific research, master's studies, professional studies, participation in projects, reflexive practice, participation in conferences and so on). Stankevič (2014) tried to find out what educational research understanding had the last (third and fourth) course students - future English teachers, referring to the evaluation of the research activity presentation given to them. Research results showed that the possessed future teachers' research activity understanding was heterogeneous, because it included such research understanding which corresponded both to scientific educational research raised requirements, and to typical features of teachers' reflexive practice or diagnostic one's own activity evaluation. More research is done, analysing teachers' research activity, teachers' research activity competence (Geležinienè, 2006; Mockus, 2011), however, there is no research analysing teacher's position regarding educational research: how teachers use educational research results, how they evaluate educational research results and recommendations, whether they are interested in educational research, if research is important for the pedagogue as a tool of improvement, whether it helps to innovatively organise the educational process.

Thus, the main research aim was - to analyse primary school teachers' position on the educational research issue. It was analysed how teachers understood the use of such research to educational practice, what the reasons were that explained the gap between educational research and educational practice, and educational research and educational practice relationship strengthening possibilities. Also, teachers' professional development needs were analysed in the aspect of educational research availability/accessibility and its use in educational practice, their expectations were evaluated.

\section{Research Methodology}

\section{General Research Characteristics}

Qualitative and partly quantitative research (of a pilot type) was carried out. A mixed research approach was applied i.e., methodological triangulation (combining qualitative and quantitative research methods for the same research project) was used in the study (Dezin, 1970; Morse, 1991). The research was conducted in the months April to June 2019. Such research is specifically recognized as "basic or generic qualitative research" (Merriam, 1998), because it has the essential characteristics of qualitative research. On the other hand, such research forms the possibilities to obtain data about the researched 
Lamanauskas, V., Augienè, D., \& Makarskaitė-Petkevičienè, R. (2020). Primary school teachers' educational research: Educational practice and professional development context, International Journal of Cognitive Research in Science, Engineering and Education (IJCRSEE), 8(3), 1-18.

phenomenon or about the phenomenon's possible new aspects (Bitinas, 2002). The research focused on the diversity of expression of the phenomenon under study.

\section{Research Sample}

One hundred six (106) primary school teachers from various Lithuanian places participated in the research. The respondents were questioned during qualification events that took place therefore, the respondents' geographical distribution is rather wide. The research was carried out during in-service training seminars/teacher competence development seminars. Teachers from all 10 counties of Lithuania participated in the research. The pilot research allows us to make assumptions about the tendencies of the problem in Lithuanian primary schools and creates purposeful conditions for further development of the necessary research tools for further in-depth research. According to Morse (1994) recommendations, the sample of 30-50 participants is suitable for such kind of research. Having evaluated Creswell's et al. (2016) position, a range of 20-30 participants is acceptable for qualitative samples. The quantitative part of the research is treated as a pilot study. Thus, researchers held the opinion, that basically a sample of randomly asked 106 teachers was suitable, seeking to formulate well-founded conclusions. It was additionally evaluated that not many variables were analysed in the research, the examined population was basically homogenic (the majority are women), such sample volume was considered appropriate (Langdridge and Hagger-Johnson, 2009; Neuman, 1997). In addition, given that the results of the research are not subject to statistic generalization, the sample is considered appropriate. The survey is also considered appropriate when it involves at least 100 people representing larger subgroups of the population (Gall et al. 2003). Only female participated in the research.

The respondents' distribution according to the length of service is given in Table 1.

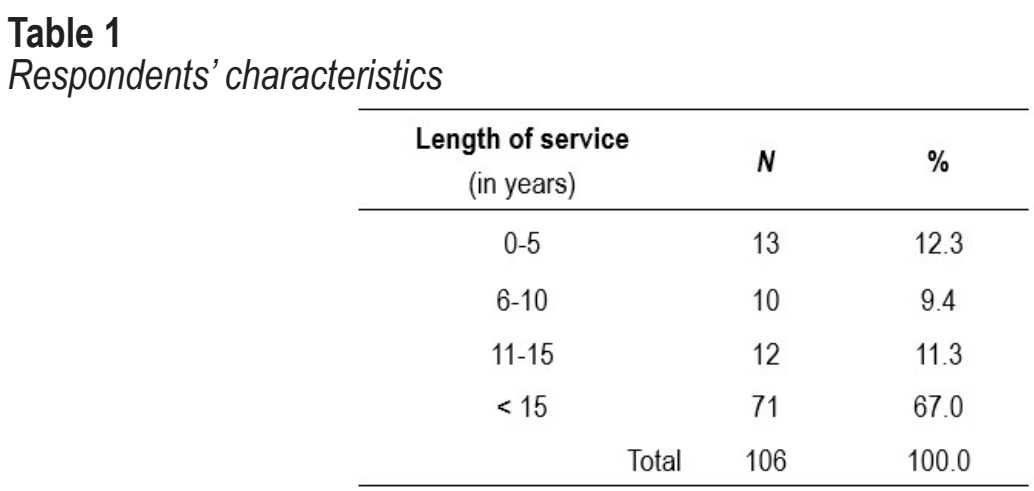

Before the research, the conducted research aim was explained for the teachers, the respondents were informed about the collected information usage purposefulness, and also the respondents' verbal agreement was obtained to take part in the research. The teachers' questionnaire survey followed basic ethical principles: respect for individual privacy, confidentiality and anonymity, justice, and voluntary and goodwill. Verbal consent to participate in the study was obtained from each study participant. The participants of the research were informed about the ongoing research, acquainted with its goals, the benefits of the research were indicated / expectations about the possible benefits for educational practice were expressed.

\section{Instrument}

The respondents were given five open-ended questions:

- What use, in your opinion, educational research has for educational practice? Please give a comment.

-What, in your opinion, are the causes of the gap between educational research and educational practice? Please give a comment.

- How, in your opinion, would be possible to strengthen educational research and educational practice relationship? Please give a comment.

- What expectations do you have from educational research and researchers? Give a comment.

- What are your professional improvement needs in the aspect of educational research availability/ accessibility and its use in educational practice? Please give a comment. 
Lamanauskas, V., Augienè, D., \& Makarskaitė-Petkevičienè, R. (2020). Primary school teachers' educational research: Educational practice and professional development context, International Journal of Cognitive Research in Science, Engineering and Education (IJCRSEE), 8(3), 1-18.

The presented questions were prepared exclusively for this research, they were analysed separately and do not form a separate measurement scale.

Quantitative instrument part contained such variables:

- The type of readable educational publications, and the frequency of reading (ranking scale was applied): read very often; sometimes/rarely; do not read at all). 8 items in total. Cronbach`s alpha - .67.

- Educational research possible influence on educational practice (ranking scale was applied: significant; partly significant, not significant).

- Exhaustive research necessity of the educational problems/spheres in the nearest future (ranking scale was applied: agree; partly agree; do not agree. 16 items in total. Cronbach's alpha - .81).

- The evaluation of educational research value for educational practice (ranking scale was applied: big value; average value; little value).

The prepared questions were discussed and validated with two experts (university professors) in the field of education working in both general education schools and universities. It is important to emphasize that in qualitative research, external validity is described by the concepts of transferability and detailed description (Bitinas et al. 2008). Transferability of a qualitative part of the research as an external validity criterion is based on the ability to transfer the results of the study to another situation or context, for example, examining the position of secondary school teachers on the research issue.

\section{Data Analysis}

The obtained research data were expressed in writing in a free answer form. Later, the collected answers were coded. Researchers tried to find similarities, differences and interrelationship between text segments and to single out clear semantic units. Thus, the smallest text component semantically differing from others was considered the analysis unit. In the primary stage, multiple reading of the text was carried out. Later, the grouping of most frequently repeating semantic units was carried out (subcategory extraction). Semantically close subcategories were joined into categories. In the last stage, interpretation and substantiation of the subcategories and categories were carried out. The researchers based content analysis on the extraction of features, which were important for the researcher, and which could be generalised.

A quantitative content analysis type was chosen, when a code system is defined, calculation results are arranged in the form of tables. It was sought to ascertain how the respondent perceived/ understood the analysed phenomenon, reflecting on his experience, referring to the researcher's presented questions. Having evaluated Mayring (2002) position, one can claim that content analysis is a valid method allowing to draw reliable conclusions, referring to the systematically analysed text (verbal data array). Such an approach allows avoiding subjective text interpretation and guarantees the analysis objectivity (Guščinskienè, 2002). Before choosing the content analysis method, the researchers made sure that there was enough material for the research and that it was representative. Semantic unit extraction and grouping were carried out independently by two researchers, seeking in this way to guarantee the analysis objectivity. Thus, the initial text analysis (text comprehension, division), definition of significant information, its grouping, categorization, comparative analysis, final text analysis were performed. This justifies the detail of the qualitative study description that helps understand that the results can be used in different contexts.

Quantitative analysis was carried out applying the main descriptive statistics measures (including calculation of absolute and relative frequencies, standard deviation, significance index). Non-parametric chi-square $\left(x^{2}\right)$ criterion was applied to ascertain possible statistical differences between variables. Spearman rank correlation coefficient rho $(\rho)$ was applied to establish a possible correlation between variables. For the reliability of the analyses, there should be up to 20 times as many participants as the total number of variables (Stevens, 2012). According to this, for the reliability of the findings, at least 100 participants are required, whereas the quantitative part of the research covered five key variables. Quantitative statistical analysis was carried out using SPSS 21 software package. 


\section{Research Results}

\section{Quantitative Analysis Results}

It was analysed how often and what educational field publications the teachers read. The results are presented in Figure 1.

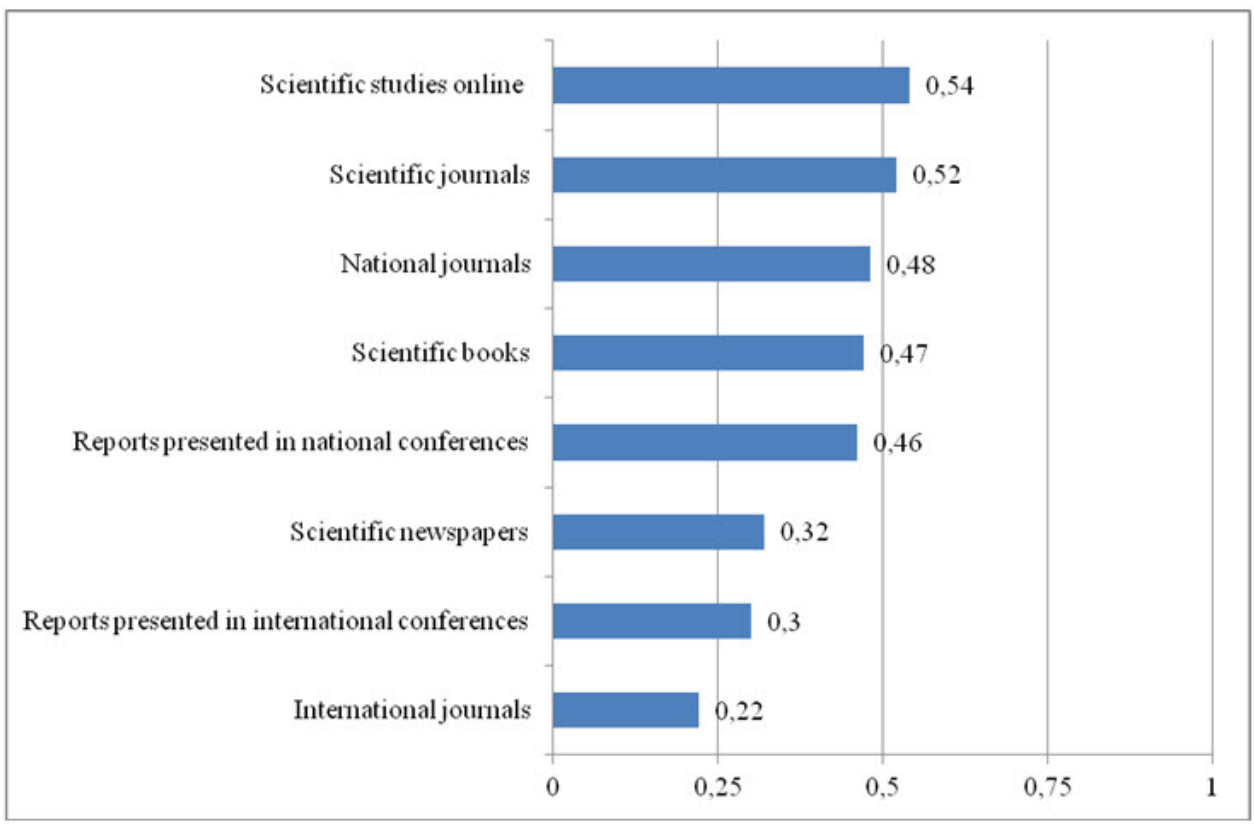

Figure 1. Educational publication type and their reading frequency.

As data in Figure 1 shows, teachers were very little interested in published educational research, they read scientific papers very little. It was ascertained that more frequently they chose those issues, which were easier accessible, i.e. internet scientific studies $(S I=.54)$, scientific journals $(S I=.52)$, national journals $(\mathrm{SI}=.48)$. The least popular were reports presented in international conferences $(\mathrm{SI}=$ $.30)$, international issues $(\mathrm{SI}=.22)$. It can be that for many informants there were no possibilities to take part in international conferences, they lacked knowledge of where to find international journal articles, and senior generation people had foreign language barrier problems. On the other hand, part of them were not accessible because of the financial costs.

It was analysed how teachers valued educational research effect on educational practice. The results are presented in Table 2.

Table 2

Evaluation of educational research effect on educational practice (N (\%)).

\begin{tabular}{lccccc}
\hline \multirow{2}{*}{ Evaluation level } & \multicolumn{3}{c}{ Length of service in years } & \multirow{2}{*}{ Total } \\
\cline { 2 - 4 } & $0-5$ & $6-10$ & $11-15$ & $<15$ & \\
\hline Significant influence & $11(84.6)$ & $9(90.0)$ & $3(25.0)$ & $39(54.9)$ & $62(58.5)$ \\
Partly significant influence & $2(15.4)$ & $1(10.0)$ & $9(75.0)$ & $28(39.4)$ & $40(37.7)$ \\
Not significant influence & $0(0.0)$ & $0(0.0)$ & $0(0.0)$ & $4(5.6)$ & $4(3.8)$ \\
\multicolumn{1}{c}{ Total } & $13(100.0)$ & $10(100.0)$ & $12(100.0)$ & $71(100.0)$ & $106(100.0)$ \\
\hline
\end{tabular}

It can be seen that $58.5 \%$ of the respondents evaluated a possible effect as significant. A smaller part discerned only partial significance, or they thought that this influence was not significant at all. It was established a statistically significant difference $\left(x^{2}=15.87, d f=6, p=.014\right)$. One can think that younger teachers value research influence as more significant than the older ones. An assumption can be made that older teachers lose motivation, willingness to be interested, perhaps they are overconfident about 
Lamanauskas, V., Augienè, D., \& Makarskaitė-Petkevičienè, R. (2020). Primary school teachers' educational research: Educational practice and professional development context, International Journal of Cognitive Research in Science, Engineering and Education (IJCRSEE), 8(3), 1-18.

their competence. in Table 3.

The value of educational research for educational practice was evaluated. The results are presented

Table 3

The value of Educational research for educational practice

\begin{tabular}{|c|c|c|}
\hline Evaluation level & $N$ & $\%$ \\
\hline Big & 53 & 50.0 \\
\hline Average & 44 & 41.5 \\
\hline Little & 9 & 8.5 \\
\hline Total & 106 & 100.0 \\
\hline
\end{tabular}

The respondents evaluated this parameter similarly, i.e. statistically significant differences regarding length of pedagogical work were not fixed $\left(X^{2}=8.62, d f=6, p>.05\right)$.

A possible relation between educational research influence on educational practice and its possible value evaluation was calculated. It is seen that these two parameters strongly correlate, i.e., $\rho=.492$, $p<.0001)$. This shows that those who valued education research influence as significant, they also valued research value for education practice in the same way.

Having performed the analysis, the most important spheres were distinguished (Educational problem questions), which should be exhaustively researched in the nearest future. The results are presented in Figure 2.

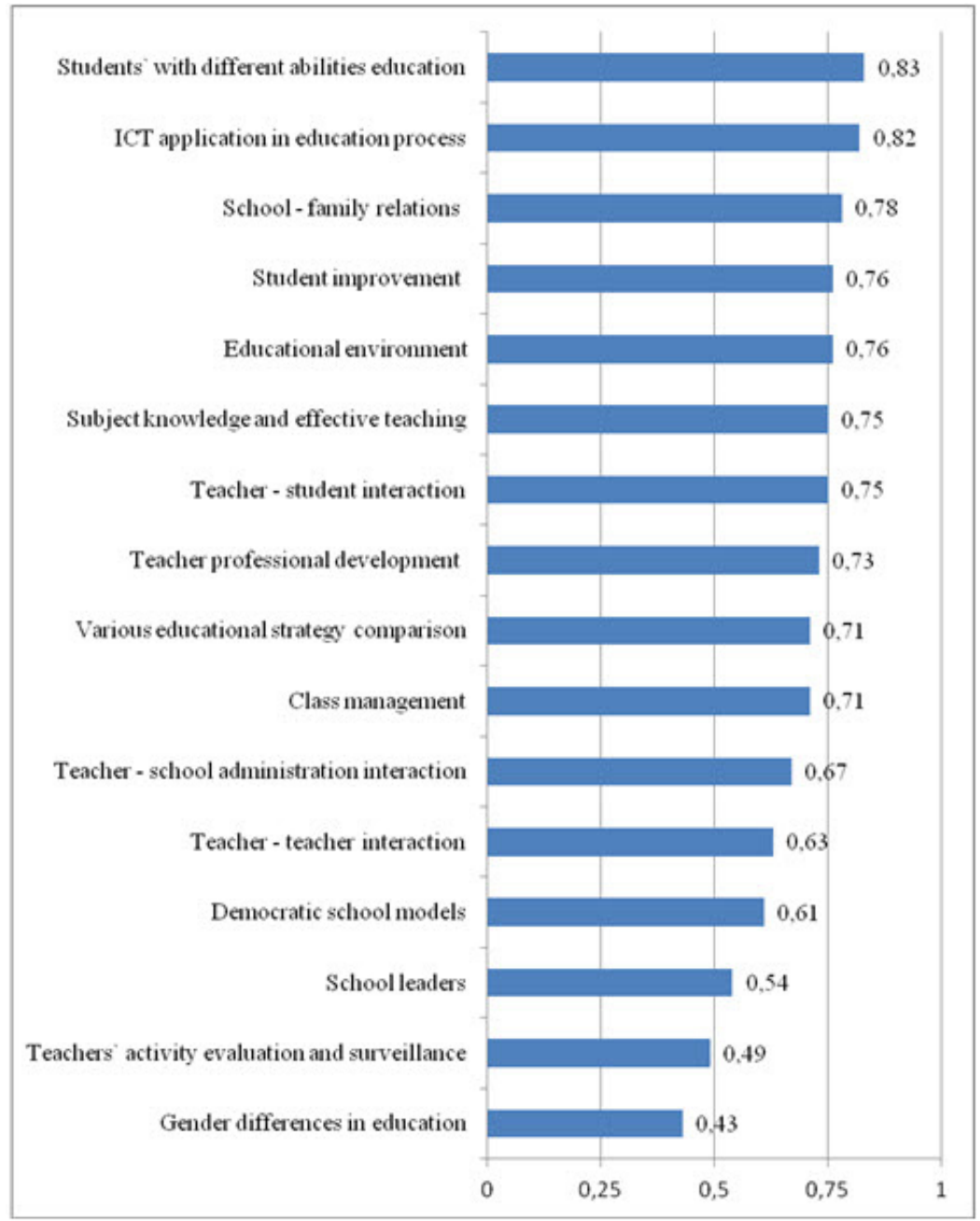

Figure 2. The most important problem spheres of educational research

The results presented in Figure 3 show that two spheres were very actual for the teachers: education of students with different abilities $(S I=.85)$ and ICT application in educational process $(S I=$ 
.82). These results reflect today's education reality. It is sought to create favourable educational conditions for all children with the help of inclusive education, which is a sufficiently new way of educational process organisation and raises a lot of questions for the teachers. It is sought to constantly modernise education process implementing ICT, that also raises new challenges for teachers. Very actual for the teachers was school - family relation problem $(\mathrm{SI}=.78)$. Today, collaboration with parents, parents' self-involvement in children's education process at school is a problematic phenomenon. Educational research areas that are very important for the teacher were - student's improvement $(\mathrm{SI}=.76)$, educational environment (SI $=.76)$, subject knowledge and effective teaching $(\mathrm{SI}=.75)$, teacher - student interaction $(\mathrm{SI}=.75)$ which are also very important for the teacher's activity in the lesson.

Educational research areas - school leaders $(\mathrm{SI}=.54)$, teachers' activity evaluation and surveillance $(\mathrm{SI}=.49)$ and gender differences in education $(\mathrm{SI}=.49)$ were basically evaluated as not significant.

\section{Qualitative Analysis Results}

The analysis was carried out how teachers valued educational research benefit for their educational practice. The results are presented in Table 4.

Table 4

Education (educational) research benefit for educational practice

\begin{tabular}{|c|c|c|c|c|c|}
\hline Category & $N(\%)$ & Subcategory & $N(\%)$ & Subcategory components & $N(\%)$ \\
\hline \multirow{16}{*}{$\begin{array}{l}\text { Significant } \\
\text { benefit }\end{array}$} & \multirow{16}{*}{$\begin{array}{l}64 \\
(64.5)\end{array}$} & \multirow{6}{*}{$\begin{array}{l}\text { Education } \\
\text { process }\end{array}$} & \multirow{6}{*}{$33(33.3)$} & Educational problems are identified/ show strengths and & $\begin{array}{l}10 \\
(10.1) \\
6(6.1)\end{array}$ \\
\hline & & & & $\begin{array}{l}\text { weaknesses } \\
\text { Research allows the education process to get better } \\
\text { fimprove }\end{array}$ & $6(6.1)$ \\
\hline & & & & Helps to better understand/cognise educational process & $4(4.1)$ \\
\hline & & & & Research results allow to reflect on educational practice & $3(3.0)$ \\
\hline & & & & Help to easier plan educational process & $2(2.0)$ \\
\hline & & & & Theoretical knowledge confirms practice & $2(2.0)$ \\
\hline & & \multirow{5}{*}{$\begin{array}{l}\text { Teacher } \\
\text { improvement }\end{array}$} & \multirow{5}{*}{$18(18.2)$} & $\begin{array}{l}\text { Develop critical thinking } \\
\text { Present research-based recommendations for teachers } \\
\text { Educational research studies help to qualitatively analyse } \\
\text { education needs }\end{array}$ & $\begin{array}{l}2(2.0) \\
2(2.0) \\
2(2.0)\end{array}$ \\
\hline & & & & The depth of benefit depends on the data receiver & $2(2.0)$ \\
\hline & & & & One can find out what was ascertained & $1(1.0)$ \\
\hline & & & & Research studies help to check, clarify certain opinions & $1(1.0)$ \\
\hline & & & & $\begin{array}{l}\text { Help the teacher to improve } \\
\text { Arouse curiosity }\end{array}$ & $\begin{array}{l}1(1.0) \\
1(1.0)\end{array}$ \\
\hline & & \multirow{5}{*}{$\begin{array}{l}\text { Situation of } \\
\text { education } \\
\text { institutions } \\
\text { Students' } \\
\text { achievements } \\
\text { Education } \\
\text { content }\end{array}$} & \multirow{2}{*}{ f $9(9.1)$} & Research shows real condition & $3(3.0)$ \\
\hline & & & & $\begin{array}{l}\text { Real educational situation is evaluated } \\
\text { Research shows a certain teaching direction }\end{array}$ & $\begin{array}{l}3(3.0) \\
3(3.0)\end{array}$ \\
\hline & & & $3(3.0)$ & One can more exactly evaluate learning achievements & $2(2.0)$ \\
\hline & & & & One can see students' achievements & $1(1.0)$ \\
\hline & & & $1(1.0)$ & Useful for creating educational programmes & $1(1.0)$ \\
\hline \multirow{5}{*}{$\begin{array}{l}\text { Partial/ } \\
\text { Little benefit }\end{array}$} & \multirow{5}{*}{$\begin{array}{l}19 \\
(19.2)\end{array}$} & \multirow{5}{*}{ Practical value } & \multirow{5}{*}{$19(19.2)$} & Research provides only partial support & \multirow{4}{*}{$\begin{array}{l}8(8.1) \\
6(6.1) \\
2(2.0) \\
2(2.0)\end{array}$} \\
\hline & & & & Little benefit/slight significance & \\
\hline & & & & Research is often only formal therefore it is of little use & \\
\hline & & & & $\begin{array}{l}\text { Educational research studies have importance for } \\
\text { educational practice, but they are not to determine }\end{array}$ & \\
\hline & & & & One can use certain advice & $1(1.0)$ \\
\hline \multirow{6}{*}{$\begin{array}{l}\text { Of no use inot } \\
\text { useful }\end{array}$} & \multirow{6}{*}{$\begin{array}{l}16 \\
(16.2)\end{array}$} & \multirow[t]{3}{*}{$\begin{array}{l}\text { Research result } \\
\text { inaccessibility }\end{array}$} & \multirow[t]{3}{*}{$9(9.1)$} & $\begin{array}{l}\text { Research is research, it does not reach educational } \\
\text { practice }\end{array}$ & $4(4.1)$ \\
\hline & & & & Research is poorly publicised & $3(3.0)$ \\
\hline & & & & Research results do not reach schools & $2(2.0)$ \\
\hline & & \multirow{2}{*}{$\begin{array}{l}\text { Research result } \\
\text { worthlessness }\end{array}$} & \multirow{2}{*}{$5(5.1)$} & Not useful in practical activity & $3(3.0)$ \\
\hline & & & & Almost of no use & $2(2.0)$ \\
\hline & & $\begin{array}{l}\text { Teacher's } \\
\text { business }\end{array}$ & $2(2.0)$ & No time to find advice in research & $2(2.0)$ \\
\hline
\end{tabular}

Note: Totally 99 semantic units were distinguished 
Lamanauskas, V., Augienè, D., \& Makarskaitė-Petkevičienè, R. (2020). Primary school teachers' educational research: Educational practice and professional development context, International Journal of Cognitive Research in Science, Engineering and Education (IJCRSEE), 8(3), 1-18.

Teachers' answers about educational research benefit for their practical activity enabled to formulate three categories: Significant benefit; Partial/little benefit; Of no use/not useful.

The first category Significant benefit $(64.5 \%)$ was of greatest significance, which obviously showed that carried out educational research was important for teachers' practical activity. In teacher's opinion, educational research provided significant use for educational process organisation, teacher's improvement, helped to identify the situation of education institutions, improved students' achievements, helped to improve educational content. Educational research was of great significance for educational process $(33.3 \%)$. Teachers indicated that educational research was of great use for educational practice $(10.1 \%)$, identified problems, showed weaknesses and strengths in education $(6.1 \%)$, enabled to improve educational practice $(6.1 \%)$. Part of the teachers discerned educational research benefit for teacher's improvement $(18.2 \%)$. They indicated that educational research provided more knowledge; developed critical thinking; research results helped to ground recommendations for teachers; helped the teacher to check, to clarify their certain attitudes, opinion, aroused curiosity, interest and so on. Part of the teachers' answers allowed claiming that educational research helped to better cognise the situation of educational institutions (9.1\%): showed real condition, evaluated situation, showed a certain teaching direction. The answers of not a big part of teachers allowed claiming that educational research helped to evaluate students' expectations (3.0\%) and was useful for education content $(1.0 \%)$ creating educational programmes.

The second category, according to its importance, was Partial/little benefit (19.2\%). Teachers' answers allowed claiming that educational research had only a certain practical value. Teachers indicated that research provided only partial help $(8.1 \%)$, had poor influence $(6.1 \%)$. The others emphasised that research was often formal, therefore, of little use; educational research had significance for educational practice but was not just determining everything; one could use only some pieces of advice and so on.

The third category was of no use/not useful $(16.3 \%)$. The answers of not a big part of teachers showed that educational research was of no use/not useful for their practical activity. The teachers' answers allowed claiming that three causes determined this. The first cause - research result inaccessibility $(9.1 \%)$. Teachers indicated that research did not reach educational practice; was little publicised and so on. The second cause - research result worthlessness (5.1\%). The third - the teacher's business $(2.0 \%)$.

Teachers' opinion analysis was carried out about possible causes, determining the gap between educational research and educational practice. The obtained data enabled to formulate three categories: Teachers' incompetence, Research result inaccessibility, Research unreliability (Table 5). 
Lamanauskas, V., Augienè, D., \& Makarskaitè-Petkevičienè, R. (2020). Primary school teachers' educational research: Educational practice and professional development context, International Journal of Cognitive Research in Science, Engineering and Education (IJCRSEE), 8(3), 1-18.

Table 5

The causes of the gap between educational research and educational practice

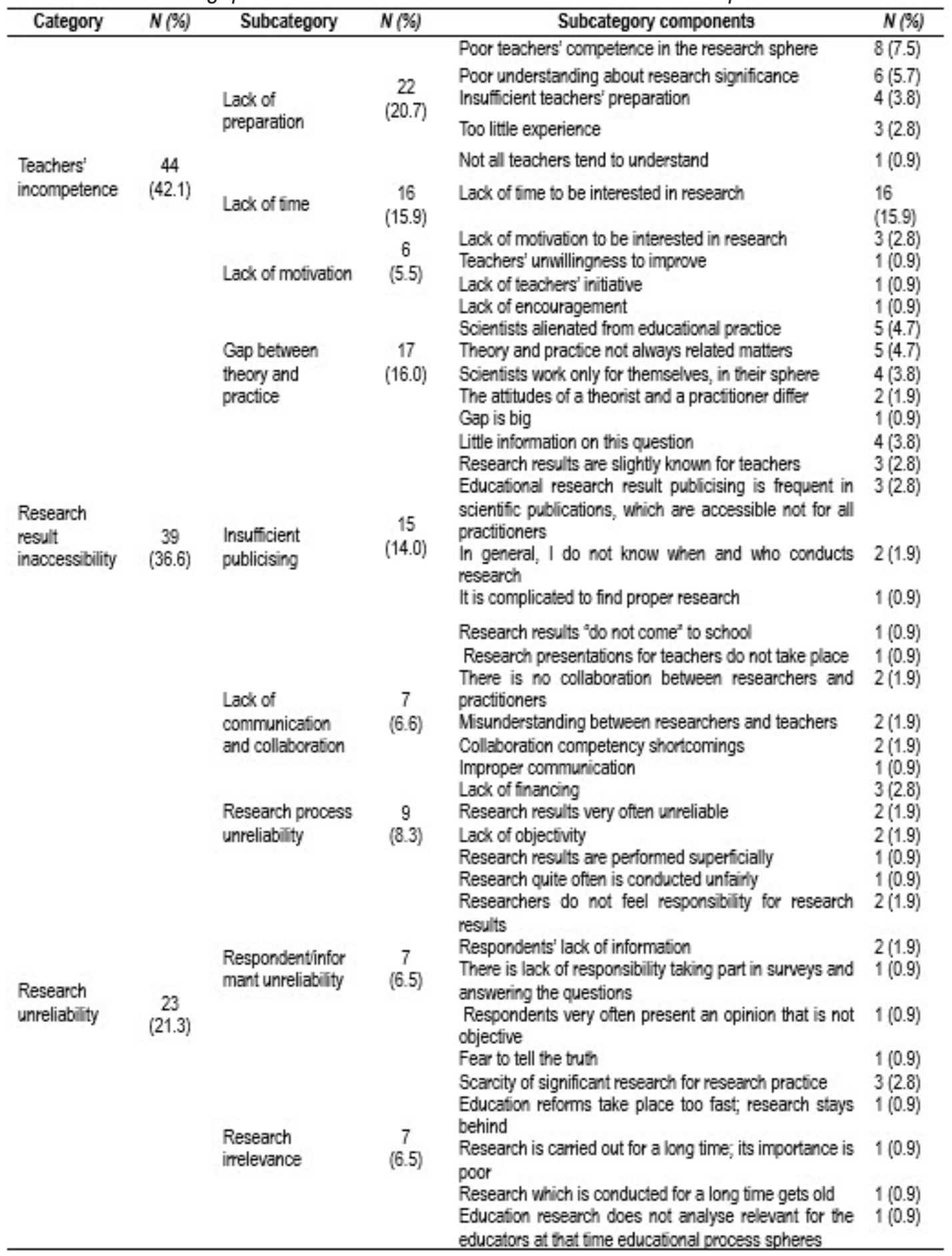

Note: Totally 106 semantic units were distinguished

The first category Teachers' incompetence was of greatest importance (42.1\%). This shows that lack of teachers' competence in this sphere usually determines the gap between educational research and practice. Teachers' answers allowed establishing three main factors, determining teachers' incompetence. The main factor was related to the lack of teachers' preparation $(20.7 \%)$ to make use of educational research results. Teachers indicated that they had poor competence in the research sphere; poor understanding about research significance; insufficient preparation; too little experience and so on. The second factor, determining teachers' incompetence, was teachers' experienced lack of time $(15.9 \%)$. The third factor was teachers' lack of motivation (5.5\%). Here the teachers indicated: unwillingness to be interested; lack of motivation to be interested in research; unwillingness to improve; lack of initiative, on 
the other hand - lack of encouragement. The obtained results revealed a lack of teachers' preparation, inability or unwillingness to actively implement educational research results to educational process practice, to make use of research results.

The second, according to its importance, was the category Research result inaccessibility (36.6\%). This showed that research result inaccessibility very often was one of the main causes determining the gap between educational research and practice. The teachers' answers allowed claiming that three factors determined research result inaccessibility. The most important factor, determining research result inaccessibility, was gap between theory and practice (16.0\%). Teachers indicated that scientists were alienated from educational practice; theory and practice were not always related matters; scientists worked only for themselves, in their sphere; the attitudes of a theorist and a practitioner differed as well. Another important factor, hindering research result accessibility, was insufficient publicising $(14.0 \%)$. Teachers gave arguments: little information on this question; research results were very little known for teachers; education result publicising was frequent in scientific publications, which were accessible not for all practitioners; in general, it was not known when and who conducted research; it was difficult to find proper research, research results "did not come" to school; research presentations for teachers did not take place. The third important factor, hindering research result accessibility, was lack of communication and collaboration $(6.6 \%)$. Teachers noticed that there was no collaboration between researchers and practitioners; there was misunderstanding between researchers and teachers; gaps of collaboration competency and so on. These statements express teachers' dissatisfaction with the existing communication and collaboration with researchers.

The third singled out category was Research unreliability (21.3\%). This shows that one of the causes determining the gap between educational research and practice was research unreliability. Teachers' answers enabled mentioning three factors. The most important factor, determining research unreliability, was the unreliability of the research process itself $(8.3 \%)$. Teachers thought that research was poorly funded; research results were often unreliable; there was lack of objectivity; research was conducted superficially, unfair and so on. The second factor determining research unreliability was respondent/informant participating in research unreliability $(6.5 \%)$. Teachers indicated that sometimes the respondents did not feel responsibility for the research results; the respondents lacked information; lacked responsibility participating in surveys and answering the questions; presented not objective information; were afraid to tell the truth. The third factor, making research unreliable, was research irrelevance $(6.5 \%)$. Teachers indicated that there was little research significant for the research practice; education reforms took place very fast and research stayed behind; research was conducted for a long time; long time conducted research was considered outdated; education research did not analyse relevant for the educators at that time educational process spheres. It is obvious that these factors and expressed teachers' opinion makes the researchers responsible for taking care of research organisation quality and necessary information dissemination.

Teachers' opinion analysis about the possibility to strengthen education content and education practice correlation was carried out. The obtained data allowed formulating three categories: Research result realisation, Research organisation, Teachers' competence development (Table 6). 
Lamanauskas, V., Augienè, D., \& Makarskaitė-Petkevičienè, R. (2020). Primary school teachers' educational research: Educational practice and professional development context, International Journal of Cognitive Research in Science, Engineering and Education (IJCRSEE), 8(3), 1-18.

Table 6

Educational research and educational practice correlation strengthening

\begin{tabular}{|c|c|c|c|c|c|}
\hline Category & $N(\%)$ & Subcategory & $N(\%)$ & Subcategory components & $N(\%)$ \\
\hline \multirow{10}{*}{$\begin{array}{l}\text { Research result } \\
\text { realisation }\end{array}$} & \multirow{10}{*}{$\begin{array}{c}30 \\
(36.6)\end{array}$} & \multirow{6}{*}{ Dissemination } & \multirow{6}{*}{$\begin{array}{c}24 \\
(29.3)\end{array}$} & Wider educational research result dissemination & $6(7.3)$ \\
\hline & & & & To introduce teachers with the research results & $6(7.3)$ \\
\hline & & & & Good experience dissemination & $4(4.8)$ \\
\hline & & & & Research results should be announced in schools & $3(3.7)$ \\
\hline & & & & Publicising activities & $3(3.7)$ \\
\hline & & & & $\begin{array}{l}\text { To present more publications on the internet or in } \\
\text { another pedagogical space }\end{array}$ & $2(2.4)$ \\
\hline & & \multirow{4}{*}{$\begin{array}{l}\text { Practical } \\
\text { realisation }\end{array}$} & \multirow{4}{*}{$6(7.3)$} & $\begin{array}{l}\text { Conducting research, concrete practically realisable } \\
\text { recommendations should be presented }\end{array}$ & $3(3.7)$ \\
\hline & & & & To analyse research-based recommendations & $1(1.2)$ \\
\hline & & & & To direct research to practical problem solving & $1(1.2)$ \\
\hline & & & & $\begin{array}{l}\text { It is constantly being searched for result employment } \\
\text { possibilities }\end{array}$ & $1(1.2)$ \\
\hline \multirow{8}{*}{$\begin{array}{l}\text { Research } \\
\text { organisation }\end{array}$} & \multirow{8}{*}{$\begin{array}{c}28 \\
(33.9)\end{array}$} & \multirow{4}{*}{$\begin{array}{l}\text { Researcher- } \\
\text { practitioner } \\
\text { collaboration }\end{array}$} & \multirow{4}{*}{$\begin{array}{c}13 \\
(15.8)\end{array}$} & $\begin{array}{l}\text { To strengthen collaboration between researchers and } \\
\text { teachers }\end{array}$ & $6(7.3)$ \\
\hline & & & & $\begin{array}{l}\text { More active collaboration between educational } \\
\text { researchers and practitioners/teachers }\end{array}$ & $5(6.0)$ \\
\hline & & & & $\begin{array}{l}\text { Specialists performing educational research should } \\
\text { collaborate closer with education institutions (schools, } \\
\text { kindergartens, day centres }\end{array}$ & $1(1.2)$ \\
\hline & & & & $\begin{array}{l}\text { Educational research organisation should be common } \\
\text { work of a theorist and a practitioner }\end{array}$ & $1(1.2)$ \\
\hline & & \multirow{2}{*}{$\begin{array}{l}\text { Teacher/practition } \\
\text { er research }\end{array}$} & \multirow{2}{*}{$\begin{array}{c}12 \\
(14.5)\end{array}$} & Practitioners should conduct research & $7(8,4)$ \\
\hline & & & & $\begin{array}{l}\text { Teachers themselves should participate more in } \\
\text { research activity }\end{array}$ & $5(6.0)$ \\
\hline & & \multirow{2}{*}{$\begin{array}{l}\text { Relationship with } \\
\text { practice }\end{array}$} & \multirow{2}{*}{$3(3.6)$} & $\begin{array}{l}\text { Researchers should be more interested in } \\
\text { educational practice }\end{array}$ & $2(2.4)$ \\
\hline & & & & $\begin{array}{l}\text { Educational researchers conducting research should } \\
\text { at least temporarily work practically }\end{array}$ & $1(1.2)$ \\
\hline \multirow{7}{*}{$\begin{array}{l}\text { Teacher } \\
\text { competence } \\
\text { development }\end{array}$} & \multirow{7}{*}{$\begin{array}{c}25 \\
(29.5)\end{array}$} & \multirow{4}{*}{$\begin{array}{l}\text { Events for } \\
\text { teachers }\end{array}$} & \multirow{4}{*}{$\begin{array}{c}17 \\
(19.8)\end{array}$} & To organise practical seminars & $\begin{array}{l}12 \\
(13.8)\end{array}$ \\
\hline & & & & To organise conferences & $2(2.4)$ \\
\hline & & & & $\begin{array}{l}\text { Meetings with competent, pedagogues- practitioners } \\
\text { conducting such research are very useful }\end{array}$ & $2(2.4)$ \\
\hline & & & & To participate in courses & $1(1.2)$ \\
\hline & & \multirow{2}{*}{ Teacher teaching } & \multirow{2}{*}{$4(4.9)$} & To teach teachers & $3(3.7)$ \\
\hline & & & & Teacher education and information & $1(1.2)$ \\
\hline & & $\begin{array}{l}\text { Motivation } \\
\text { encouragement }\end{array}$ & $4(4.8)$ & $\begin{array}{l}\text { To increase teachers' motivation to be interested in } \\
\text { research }\end{array}$ & $4(4.8)$ \\
\hline
\end{tabular}

Note: Totally 83 semantic units were distinguished

The first category Research result realisation was of greatest importance (36.6\%). It is obvious that this was one of the basic ways seeking to strengthen educational research and educational practice relationship. Teachers' expressed opinion allows claiming that two action directions would influence research result realisation. The first direction was dissemination (29.3\%). The teachers claimed that seeking research result dissemination, it was necessary to introduce teachers with the research results (7.3\%), to spread good experience (4.8\%). In their opinion, it was necessary to announce research results at schools; publicising activities were important; wider educational research dissemination was necessary; it was important to present more publications on the internet or in another pedagogical space, and so on. The second direction was practical realisation (7.3\%). Seeking that practical research result realisation take place, in teachers' opinion, it was important to present concrete practically realisable recommendations conducting research; to analyse research-based recommendations; to direct research to practical problem solving; to constantly search result employment possibilities.

The second category, according to its importance, was Research organisation (33.9\%), revealing teachers' opinion about the possibility to strengthen the relation between educational research and education practice. Having analysed teachers' opinion, three important research organisation aspects emerged. Firstly, in teachers' opinion, seeking to strengthen educational research and educational practice relation organising educational research, researcher and practitioner collaboration (15.8\%) was necessary. 
Teachers indicated that it was necessary to strengthen collaboration between researchers and teachers (external effect), collaboration between educational researchers and practitioners had to be more active; educational research organisation had to be common work of a theorist and a practitioner. Secondly, teacher/practitioner research should be important (14.5\%). Teachers pointed out that practitioners should conduct research; teachers themselves should more participate in research activity. Thirdly - organising research, relationship with practice was necessary (3.6\%). Teachers indicated that researchers should be more interested in educational practice; researchers conducting research should at least temporarily work practically.

The third, according to its importance, was the category Teacher competence development (29.5\%). This category reveals that seeking to strengthen educational research and educational practice relationship, teachers should have necessary competences. Teachers' expressed opinion allows claiming that first of all, events for the teachers (19.8\%): practical seminars, conferences, meetings with competent pedagogues practitioners conducting such research (anyway, teachers participating in the research indicated seminars six times more than any other forms of events) would be of service. Teacher teaching (4.9\%), motivation encouragement (4.8\%) were also important.

Teachers' opinion about possessed expectations from educational research and researchers was analysed. The obtained results enabled discerning three categories: Support provision for the teacher, Research organisation improvement, Research result publicising (Table 7).

Table 7

Teachers' expectations related to educational research and researchers

\begin{tabular}{|c|c|c|c|c|c|}
\hline Category & $N(\%)$ & Subcategory & $N(\%)$ & Subcategory components & $N(\%)$ \\
\hline \multirow{13}{*}{$\begin{array}{l}\text { Provision of } \\
\text { support for the } \\
\text { teacher }\end{array}$} & \multirow{13}{*}{$\begin{array}{c}37 \\
(53.2)\end{array}$} & \multirow{5}{*}{$\begin{array}{l}\text { Provision of practical } \\
\text { advice }\end{array}$} & \multirow{5}{*}{$\begin{array}{c}29 \\
(41.9)\end{array}$} & $\begin{array}{l}\text { To provide practical advicel advice for } \\
\text { teachers }\end{array}$ & $13(18,6)$ \\
\hline & & & & $\begin{array}{l}\text { Necessary concrete recommendations } \\
\text { for teachers }\end{array}$ & $5(7.2)$ \\
\hline & & & & To provide certain insights & $3(4.3)$ \\
\hline & & & & $\begin{array}{l}\text { To provide clear and concrete } \\
\text { conclusions }\end{array}$ & $3(4.3)$ \\
\hline & & & & $\begin{array}{l}\text { To provide practical use, but not only } \\
\text { research just for research }\end{array}$ & $3(4.3)$ \\
\hline & & \multirow{5}{*}{$\begin{array}{l}\text { Organisation of the } \\
\text { teaching }\end{array}$} & \multirow{5}{*}{$\begin{array}{c}8 \\
(11.3)\end{array}$} & To provide support for the teachers & $2(2.8)$ \\
\hline & & & & To involve teachers in research & $4(5.7)$ \\
\hline & & & & Train teachers & $2(2.8)$ \\
\hline & & & & Practical activities are necessary & $1(1.4)$ \\
\hline & & & & $\begin{array}{l}\text { To improve knowledge, to find out } \\
\text { novelties }\end{array}$ & $1(1.4)$ \\
\hline & & \multirow{3}{*}{$\begin{array}{l}\text { Researcher and teacher } \\
\text { collaboration }\end{array}$} & \multirow{3}{*}{$\begin{array}{c}9 \\
(12.7)\end{array}$} & $\begin{array}{l}\text { Closer/nearer scientist collaboration } \\
\text { with teachers }\end{array}$ & $6(8.6)$ \\
\hline & & & & $\begin{array}{l}\text { Bigger intercommunication and } \\
\text { collaboration with teachers }\end{array}$ & $2(2.8)$ \\
\hline & & & & Qualitative collaboration and teachings & $1(1.4)$ \\
\hline \multirow{6}{*}{$\begin{array}{l}\text { Research } \\
\text { organisation } \\
\text { improvement }\end{array}$} & \multirow{6}{*}{$\begin{array}{c}21 \\
(29.8)\end{array}$} & \multirow[t]{2}{*}{ Feedback assurance } & \multirow[t]{2}{*}{$\begin{array}{c}6 \\
(8.6)\end{array}$} & $\begin{array}{l}\text { Various questionnaires usually reach } \\
\text { schools, but the results are not known }\end{array}$ & $3(4.3)$ \\
\hline & & & & Lack of research result feedback & $3(4.3)$ \\
\hline & & Relation with practice & 4 & $\begin{array}{l}\text { In order research corresponds to } \\
\text { practice }\end{array}$ & $3(4.3)$ \\
\hline & & strengthening & $(5.7)$ & $\begin{array}{l}\text { It is necessary to solve problems, not } \\
\text { only to reveal them }\end{array}$ & $1(1.4)$ \\
\hline & & Content actualisation & $1(1.4)$ & $\begin{array}{l}\text { It is important to go deep both into } \\
\text { universal and specific things }\end{array}$ & $1(1.4)$ \\
\hline & & Research ethics & $1(1.4)$ & $\begin{array}{l}\text { Researchers have to adhere to ethical } \\
\text { principles }\end{array}$ & $1(1.4)$ \\
\hline & & & & Bigger research result dissemination & $6(8.6)$ \\
\hline & & & & $\begin{array}{l}\text { To create an interactive basis of } \\
\text { educational research and researchers }\end{array}$ & $3(4.2)$ \\
\hline $\begin{array}{l}\text { Research result } \\
\text { publicising }\end{array}$ & $\begin{array}{c}12 \\
(17.0)\end{array}$ & Dissemination & $\begin{array}{c}12 \\
(17.0)\end{array}$ & $\begin{array}{l}\text { In order research does not remain only } \\
\text { in paper }\end{array}$ & $2(2.8)$ \\
\hline & & & & $\begin{array}{l}\text { Concrete research description, visual } \\
\text { material and so on }\end{array}$ & $1(1.4)$ \\
\hline
\end{tabular}

Note: Totally 70 semantic units were distinguished 
Lamanauskas, V., Augienè, D., \& Makarskaitė-Petkevičienè, R. (2020). Primary school teachers' educational research: Educational practice and professional development context, International Journal of Cognitive Research in Science, Engineering and Education (IJCRSEE), 8(3), 1-18.

The first category Provision of support for the teacher was the most significant (53.2\%). The great majority of teachers expected provision of practical advice from educational research and researchers $(41.9 \%)$. Teachers would like to be provided with practical advice; concrete recommendations; certain insights; clear and concrete conclusions. It was important for the teachers that research provided practical use, support, and was not research just for research. Teachers also expected organisation of the teaching $(11.3 \%)$. They thought that it was important to involve teachers in research; to train teachers; to organise practical activities; it was important for the teachers to improve knowledge, to find out novelties.

The second category was Research organisation improvement $(29.8 \%)$, showing that teachers expected better research organisation quality. Firstly, teachers expected researcher and teacher collaboration (12.7\%). Teachers expected closer, nearer, direct, qualitative collaboration between scientists and teachers. Teachers expected feedback assurance (8.6\%). They noticed that usually various questionnaires reached schools, but the results were not known. Teachers expected relation with practice strengthening $(5.7 \%)$. It was important for them that the research corresponded to practice; it was important to solve problems, and not only to reveal them. Teachers expected content actualisation from educational research and researchers (1.4\%) i.e. it was important to go deep both into universal and specific things. It was hoped for the research ethics assurance (1.4\%) i.e. it was important that researchers adhered to ethical principles.

The third, according to its importance, was the category Research result publicising (17.0\%). It is obvious that teachers expected better research result dissemination. Teachers would like that an interactive educational research and researchers' basis was created, that research did not remain only in paper, they would like concrete research description, visual material and so on.

Having carried out teachers' opinion analysis about professional improvement needs regarding educational research accessibility/availability and its use in educational practice, two categories were formulated: Competence development and Research result usefulness (Table 8). 
Lamanauskas, V., Augienè, D., \& Makarskaitė-Petkevičienè, R. (2020). Primary school teachers' educational research: Educational practice and professional development context, International Journal of Cognitive Research in Science, Engineering and Education (IJCRSEE), 8(3), 1-18.

\section{Table 8}

Teachers' professional development needs in the aspect of educational research study accessibility/ availability and its use in educational practice

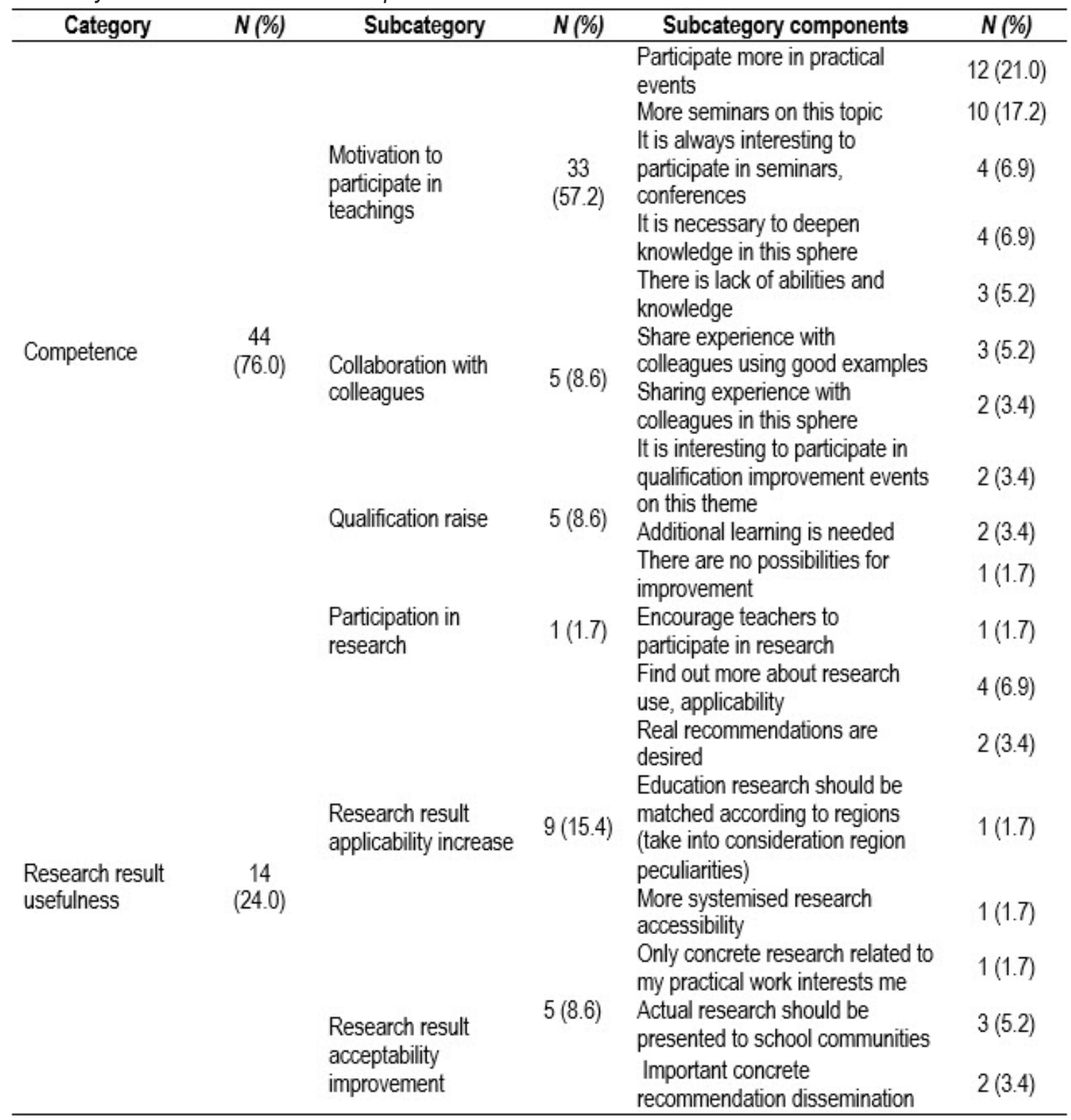

Note: Totally 58 semantic units were distinguished

The first category, Competence development, was of great significance $(76.0 \%)$. It is obvious that the majority of teachers professional improvement needs in the aspect of educational research accessibility/ availability and its use in educational practice related to the new competence acquisition and development. Teachers' opinion analysis allows claiming that the development of these competences should take place in three directions. Firstly, teachers' motivation to participate in teachings should be encouraged and supported (57.2\%). Teachers claimed that it was important to more participate in practical events; more seminars were necessary on this theme. They indicated that it was always interesting to participate in seminars, conferences, they acknowledged that it was necessary to deepen knowledge in this sphere, that there was lack of abilities and knowledge. Secondly, collaboration with colleagues was important (8.6\%). Teachers noticed that it was important to share experience with colleagues in this sphere; to use good colleagues' examples. Thirdly, for the development of these competences, qualification raise was important $(8.6 \%)$. The teachers noted that it was interesting to participate in qualification improvement events on this theme and additional learning was necessary. Fourthly, for the development of these competences, it was also important participation in research $(1.7 \%)$ therefore, it was necessary to 
Lamanauskas, V., Augienè, D., \& Makarskaitė-Petkevičienè, R. (2020). Primary school teachers' educational research: Educational practice and professional development context, International Journal of Cognitive Research in Science, Engineering and Education (IJCRSEE), 8(3), 1-18.

encourage teachers to participate in a research study.

The second category, Research result usefulness, $(24.0 \%)$ allows claiming that part of the teachers related professional improvement needs regarding educational research accessibility/availability and its use in educational practice firstly to research result applicability increase $(15.4 \%)$ (it was important for the teachers to find out more about research use, application, real recommendations are desired, and educational research itself should be matched according to regions (to take into consideration region peculiarities and so on), secondly, to research result accessibility increase (8.6\%) (actual research should be presented for school communities, concrete recommendation dissemination is important).

\section{Discussion}

The conducted research aimed to analyse primary school teachers' position on educational research question. It is obvious that complexity and uncertainty are characteristic features of education, teachers' professionality depends on their ability to make a good decision, to choose from various alternatives and to learn from their experience (Weinberger, 2018). The conducted research showed that teachers have both positive and negative positions regarding educational research. This supports the other researchers' position as well that teachers have mixed opinions both positive and negative (Behrstock-Sherratt, et al., 2011). One can think that a majority of teachers understand the use of educational research, first of all, as a possibility to improve educational practice. It is often stated in scientific literature that teacher research is a form of action research, research designed by practitioners, besides, first of all seeking practical purposes (Stringer, 2007). Such position is basically narrow because teacher research takes many forms and serves a range of purposes (Stremmel, 2007). In spite of positive educational research study evaluation, teachers rather rarely are interested in them. This also supports the other researchers' position, that teachers practitioners rarely use educational research (Lysenko et al., 2014).

The conducted research results affirm a large gap between educational research and educational practice. Teachers are poorly interested in scientific information resources except those that are easily acceptable. It has been noticed that senior teachers are significantly less interested in educational research and its results. One can agree with the other researchers' position that it would be necessary to value the gap between educational research and educational practice as a complex and differentiated phenomenon (Vanderlinde and van Braak, 2010). Finally, doubts exist due to educational research appropriateness for teachers because its performance from academic standpoint is rather strict (Rodrigues, 2008).

Support for the teacher in educational research methodology sphere is very important. Teachers relate big expectations to researchers, who according to them, could give qualified support. According to researchers, teachers develop scientific research and theory through their practice, theory and practice are seen as dialectical, determining one another (Lofthouse, 2014). Teachers need much bigger individual support (Hathorn and Dillon, 2018). Researchers accentuate that seeking to encourage teachers to do some research, certain stimuli are necessary for teachers, building a support network and support (Cochran-Smith and Lytle, 1990).

Research revealed that teachers discerned the necessity to strengthen educational research and educational practice relationship. One of the ways is teachers' involvement in research organising and conducting. The research studies carried out by other researchers show that self-involvement in research activity has influence on teacher practitioner opinion about educational research, and on their perceived abilities to carry out them (Cousins and Walker, 2000).

Teacher willing to accomplish the requirements raised for him and society's expectations, has to be open to novelties, creative, determined to constantly renew his knowledge, to know new teaching methods and teaching techniques. Therefore, research activity is educational practice part of a contemporary teacher enabling to deeper analyse educational situations. Contemporary teacher researcher is a practitioner constantly analysing their activity, conducting pedagogical activity research. However, not less important is teacher's ability to understand the importance of scientist researcher carried out educational research, the ability to use research results and recommendations organising educational process. It is highly probable that teacher who is interested in the newest education research and is able to use the research results, can more successfully construct the teaching content, teaching/learning methods and forms. The activity of such a teacher is more creative, more innovative, because constant interest in the newest educational research results can help the teacher to get answers to the emerging questions, to help deeper understand the educational process, to find problem solution ways, encourages to implement novelties and to create himself innovative ideas.

The research revealed the necessity to improve teachers' professional qualification in research 
methodology sphere. Thus, it is important to motivate, to induce teachers participate in various qualification improvement events. If an assumption is made that research has influence on educational practice, it is important that teachers are provided wider opportunities to continue professional learning i.e. to provide them with knowledge and experience, in order they can productively involve both in carried out scientific research and to conduct the research themselves (Everton et al., 2002).

It is important to motivate the teachers to be interested in educational research results. It is obvious that teacher will be interested in educational research results and recommendations if they understand their importance and will see possible result applicability and effectiveness organising educational process. Therefore, it is necessary to help the teacher understand educational research content and practical use. It is necessary to encourage teachers not only to take part in educational research together with researchers, but also to participate in conferences, during which the newest research is presented, to induce interest in scientific press.

\section{Conclusions and Implications}

The majority of teachers thought that educational research provided significant use for their practical activity: influenced educational process organisation, teacher's improvement, helped to ascertain the situation of educational institution, improved students' achievements, helped to improve educational content. Part of the teachers thought that educational research had partial/little benefit, which was usually related to narrow practical activity. Only a small part of teachers thought that educational research was of no use/useless for their practical activity because research results were poorly accessible, not publicised or research results were worthless.

It has been stated that lack of teacher competence in this sphere usually determines the biggest gap between educational research and educational practice. Teachers lack preparation, motivation, there is lack of time. Part of the teachers pointed out that research result unacceptability and research unreliability determined the gap between educational research and educational practice.

In teachers' opinion, basic ways seeking to strengthen educational research and educational practice relationship were research result realisation (research result dissemination has to be improved and practical research implementation is necessary), research organisation (researcher and practitioner collaboration is necessary, teacher/practitioner involvement in research process, research relationship with practice actualisation) and teacher competence development (events for teachers are necessary, teacher training and motivation encouragement are important).

Teachers expected support for the teacher from educational research and researchers (practical advice, organisation of teaching), research organisation improvement (researcher and teacher collaboration is necessary, feedback assurance, content actualisation, research ethics) and research result publicising (research result dissemination and accessibility are necessary).

It has been stated that teachers relate professional improvement needs regarding educational research accessibility/availability and its use in educational practice to teacher competence development (it is necessary to motivate teachers to participate in teachings, raise qualification, participate in research, collaborate with colleagues), and to research result usefulness (it is necessary to improve research result accessibility and applicability).

The results of educational research should be implemented into pedagogical practice as soon as possible. Therefore, it is very important that teachers understand the practical significance of research and its positive impact on the educational process and would like to actively participate in educational research and use its results in practice. The most effective way to help teachers inform about new research and ideas would be through a pedagogical press/media. Of course, some teachers use specialized websites (e.g., www.ikimokyklinis.It - for pre-school professionals and parents), where teachers share their experiences, are introduced to didactic innovations and educational research. However, not all subject teachers are linked by such sites. Lithuanian primary school teachers have gathered in several Facebook groups, but here they more often solve problems that arise here and now, share the educational experience. Effective methodological practical conferences, special presentation days of educational research, etc. are effective for the dissemination of educational research. During them, appropriate conditions are created for researchers to present their research, discuss with practitioners, reveal the practical use of research, and answer questions important to teachers. This would ensure the dissemination of research results and ideas, reduce the gap between theory and practice, and encourage collaboration between researchers and teachers. Teachers and students who participate in the research receive feedback, which usually motivates them to achieve even better results. Researchers themselves must listen to the expectations 
Lamanauskas, V., Augienè, D., \& Makarskaitė-Petkevičienè, R. (2020). Primary school teachers' educational research: Educational practice and professional development context, International Journal of Cognitive Research in Science, Engineering and Education (IJCRSEE), 8(3), 1-18.

of practitioners and provide practical guidance based on the results of their research, and guarantee practitioners feedback on the practical benefits of research.

It is no less important to involve teachers in the organization and conduct of educational research itself. Likely, such activities would positively promote the cooperation of younger and older teachers in schools, influence the motivation of some teachers to use research results in pedagogical practice, increase confidence in research results, promote cooperation between theorists and practitioners.

To reduce the gap between educational research and educational practice, it is important to provide special training and continuous in-service training for teachers, during which their research competence would be developed. This would strengthen teachers' confidence in their abilities, encourage initiative, interest in searching for new ideas, and help to gain a deeper understanding of the benefits of educational research.

\section{Acknowledgments}

The authors would like to thank the primary school teachers from Lithuania for their substantial assistance in the participation of the research.

\section{Conflict of interests}

The authors declare no conflict of interest.

\section{References}

Bitinas, B. (1998). Ugdymo tyrimu metodologija [Educational research methodology]. Jošara.

Bitinas, B. (2002). Pedagoginès diagnostikos pagrindai [Basics of pedagogical diagnostics]. Vilniaus pedagoginio universiteto leidykla.

Bitinas, B., Rupšienė, L., \& Žydžiūnaitė, V. (2008). Kokybiniu tyrimy metodologija [Qualitative research methodology]. Socialiniu mokslu kolegija.

Beycioglu, K., Ozer, N., \& Ugurlu, C. T. (2010). Teachers' views on educational research. Teaching and Teacher Education, 26(4), 1088-1093. https://doi.org/10.1016/j.tate.2009.11.004

Behrstock-Sherratt, E., Drill, K., \& Miller, S. (2011). Is the supply in demand? Exploring how, when, and why teachers use research (Revised Edition). AIR: American Institute for Research. https://www.air.org/sites/default/files/downloads/ report/Exploring\%20How\%20Teachers\%20Use\%20Research_Jan\%2011.pdf

Broekkamp, H., \& van Hout-Wolters, B. (2007). The gap between educational research and practice: A literature review, symposium, and questionnaire. Educational Research and Evaluation, 13(3), 203-220. http://dx.doi. org/10.1080/13803610701626127

Cekic, O., Ozturk, H., \& Apaydin, S. (2018). Teachers' views on educational research. Ahi Evran University Journal of Kirsehir Education Faculty, 19(1), 880-902.

Cousins, J. B., \& Walker, C. (2000). Predictors of educators' valuing of systematic inquiry in schools. Canadian Journal of Program Evaluation, Special Edition, 25-52.

Cochran-Smith, M., \& Lytle, S. L. (1990). Research on teaching and teacher research: The issues that divide. Educational Researcher, 19(2), 2-11. https://doi.org/10.3102/0013189X019002002

Creswell, J. W., \& Poth, C. N. (2016). Qualitative inquiry and research design: Choosing among five approaches. Sage publications.

Dezin, N. K. (1970). The research act: A theoretical introduction to sociological methods. Aldine Publishing.

Drill, K., Miller, S., \& Behrstock-Sherratt, E. (2013). Teachers' perspectives on educational research. Brock Education: A Journal of Educational Research and Practice, 23(1), 3-17 https://doi.org/10.26522/brocked.v23i1.350

Ekız, D. (2006). Primary school teachers' attitudes towards educational research. Educational Sciences: Theory \& Practice, 6(2), 395-402. https://www.academia.edu/1469940/Primary_School_Teachers_Attitudes_towards_Educational_Research

Everton, T., Galton, M., \& Pell, T. (2002). Educational research and the teacher. Research Papers in Education Policy and Practice, 17(4), 373-401. https://doi.org/10.1080/0267152022000031388

Gall, M. D., Borg, W. R., \& Gall, J. P. (2003). Educational research: An introduction (7 $7^{\text {th }}$ Ed.). Pearson.

Geležinienè, R. (2006). Mokytojas kaip tyrëjas: koncepto operacionalizacija ir veiklos perspektyva ugdant emociju ir elgesio problemu turinčius vaikus [Teacher as a researcher: Operationalisation of the concept and prospects in educating students with emotional and behaviour difficulties]. Specialusis ugdymas / Special Education, 2(15), 27-36.

Guščinskienè, J. (2002). Taikomoji sociologija: struktūrinés loginės schemos ir komentarai [Applied sociology: Structural logical schemes and comments]. Technologija.

Gu, L., \& Wang, J. (2006). School-based research and professional learning: An innovative model to promote teacher professional development in China. Teaching Education, 17(1), 59-73. https://doi.org/10.1080/10476210500528079

Hathorn, C., \& Dillon, A. M. (2018). Action research as professional development: Its role in education reform in the United Arab Emirates. Issues in Educational Research, 28(1), 99-119. http://www.iier.org.au/iier28/hathorn.pdf

Janiūnaitè, B. (2004). Edukacinés novacijos ir ju diegimas [Educational innovations and their implementation]. Technologija.

Lamanauskas, \& Augienè, D. (2016). Scientific research activity of students pre-service teachers of sciences at university: Significance, readiness, effectiveness and career aspects. Journal of Baltic Science Education, 15(6), 746-758. http:// www.scientiasocialis.It/jbse/?q=node/539 
Lamanauskas, V., Augienè, D., \& Makarskaitė-Petkevičienè, R. (2020). Primary school teachers' educational research: Educational practice and professional development context, International Journal of Cognitive Research in Science, Engineering and Education (IJCRSEE), 8(3), 1-18.

Langdridge, D., \& Hagger-Johnson, G. (2009). Introduction to research methods and data analysis in psychology. Pearson Education.

Lofthouse, R. M. (2014). Engaging in educational research and development through teacher practitioner enquiry; a pragmatic or naïve approach? Education Today, 64(4), 13-19. http://eprints.leedsbeckett.ac.uk/3951/

Lysenko, L. V., Abrami, P. C., Bernard, R. M., Dagenais, C., \& Janosz, M. (2014). Educational research in educational practice: Predictors of use. Canadian Journal of Education, 37(2), 1-26. https://journals.sfu.ca/cje/index.php/cje-rce/article/ view/1477

Mayring, P. (2002). Qualitative content analysis: Research instrument or mode of interpretation? In M. Kiegelmann (Ed.), The role of the researcher in qualitative psychology (pp. 139-148). Ingeborg Huber.

Marcos, J. J. M., \& Tillema, H. (2006). Studying studies on teacher reflection and action: An appraisal of research contributions. Educational Research Review, 1(2), 112-132. https://doi.org/10.1016/j.edurev.2006.08.003

Merriam, S. B. (1998). Qualitative research and case study applications in education. Revised and expanded from" Case study research in education" ( $2^{\text {nd }}$ ed.). Jossey-Bass Publishers. https://eric.ed.gov/?id=ED415771

Mockus, K. (2011). Mokslinis ugdymo (-si) veiksniu pažinimas mokykloje - pilietiškumo ugdymo požymis [The scientific knowledge of educational factors at school - the educational feature of public spirit]. Tiltai, 3(56), 215-226.

Morse, J. M. (1994). Designing funded qualitative research. In Denizin, N. K., \& Lincoln, Y. S. (Eds.), Handbook of qualitative research ( $\left.2^{\text {nd }} \mathrm{Ed}\right)$. Sage.

Morse, J. M. (1991). Approaches to qualitative-quantitative methodological triangulation. Nursing research, 40(2), $120-123$. https://journals.Iww.com/nursingresearchonline/Citation/1991/03000/Approaches_to_Qualitative_Quantitative.14.aspx

Neuman, W. L. (1997). Social research methods: Qualitative and quantitative approaches $\left(3^{\text {rd }}\right.$ Ed.). Allyn and Bacon.

Nezvalova, D. (2011). Can be the preservice science teacher a researcher? Problems of Education in the 21st Century, 37 , 90-97. http://www.scientiasocialis.It/pec/node/files/pdf/vol37/90-97.Nezvalova_Vol.37.pdf

Pečiuliauskienè, P. (2008). Būsimuju mokytoju tiriamosios veiklos ir vadovavimo tiriamajai veiklai kompetencija: palyginamasis aspektas [Pre-service teachers' competence in research and conducting research activity: The comparative aspect] Pedagogika / Pedagogy, 91, 35- 41.

Rodrigues, S. (2008). An appraisal of the criticisms of educational research in recent years. Education-Line, 1-4. http:// ecommons.aku.edu/pakistan_ied_pdck/50

Shreeve, A. (2004). Doing and using educational research: Engaging researchers, practitioners and policy makers in productive partnerships. Educar, 34, 85-95. https://www.raco.cat/index.php/Educar/article/download/20801/20641

Stankevič, E. (2014). Būsimu anglu kalbos mokytoju edukaciniu tyrimy samprata: Lietuvos edukologijos universiteto atvejis [The concept of educational research for future English language teachers: The case of the Lithuanian University of Educational Sciences]. Kalba ir kontekstai / Language in Different Contexts, 6(1), 260-271.

Stevens, J. P. (2012). Applied multivariate statistics for the social sciences. Routledge.

Stremmel, A. (2007). The value of teacher research: Nurturing professional and personal growth through inquiry. Voices of Practitioners, 2(3), 1-9. https://www.naeyc.org/sites/default/files/globally-shared/downloads/PDFs/resources/pubs/ Value\%20of\%20Teacher\%20Research.pdf

Stringer, E. T. (2007). Action research (3rd Ed.). Sage.

Vanderlinde, R., \& van Braak, J. (2010). The gap between educational research and practice: Views of teachers, school leaders, intermediaries and researchers. British Educational Research Journal, 36(2), 299-316. https://doi. org/10.1080/01411920902919257

Vilkonis, R., \& Vilkonienè, M. (2009). Lietuvos bendrojo lavinimo mokykloje pedagogu atliekami edukaciniai tyrimai: situacijos analizè [Teachers' educational researches carried out at the Lithuanian comprehensive school: The situation analysis]. Mokytoju ugdymas / Teacher Education, 12(1), 44-57.

Weinberger, Y. (2018). Using qualitative research methods to cope with the educational complexity. Journal of Education and Human Development, 7(1), 135-145. https://doi.org/10.15640/jehd.v7n1a16 